\title{
Osseous Metaplasia
}

National Cancer Institute

\section{Source}

National Cancer Institute. Osseous Metaplasia. NCI Thesaurus. Code C35859.

Heterotopic formation of normal bone within soft tissue. 